\title{
RESOURCE- SAVING TECHNOLOGY OF RECTIFIED ETHYL ALCOHOL
}

\author{
A. Ukrainets, Y. Buliy, P. Shiyan, A. Kuts \\ National University of Food Technologies
}

\begin{tabular}{|c|c|}
\hline Key words: & ABSTRACT \\
\hline $\begin{array}{l}\text { Rectification } \\
\text { Bottom liquid } \\
\text { Ethyl alcohol } \\
\text { Hydroselection } \\
\text { Recycling } \\
\text { Impurities }\end{array}$ & $\begin{array}{l}\text { The technology of rectified ethyl alcohol, which allows to } \\
\text { increase the separation efficiency main, part of intermediate } \\
\text { and final impurities of alcohol in distillation and recti- } \\
\text { fication plants with minimal water consumption for hydro- } \\
\text { selection. A hardware-technological scheme of the distilla- } \\
\text { tion plant is presented, in accordance with which to conduct }\end{array}$ \\
\hline $\begin{array}{l}\quad \text { Article history: } \\
\text { Received } 10.11 .2017 \\
\text { Received in revised form } \\
27.11 .2017 \\
\text { Accepted } 21.12 .2017 \\
\end{array}$ & $\begin{array}{l}\text { hydrocelection there is recycling of the bottom liquid of the } \\
\text { column for extractive distillation in acceleration column, } \\
\text { bottom liquid of acceleration column is in epuration column, } \\
\text { and bottoms liquid of alcohol column is in the column for } \\
\text { extractive distillation. Studies of the effect of the proposed }\end{array}$ \\
\hline $\begin{array}{l}\text { Corresponding author: } \\
\text { A. Ukrainets } \\
\text { E-mail: } \\
\text { npnuht@ukr.net }\end{array}$ & $\begin{array}{l}\text { technology in the production mediumare conducted. It is } \\
\text { established that its use allows to reduce specific consump- } \\
\text { tion of softened water and energy consumption for heating } \\
\text { by up to } 80 \% \text { in comparison with the standard schemes of } \\
\text { distillation and rectification plants. }\end{array}$ \\
\hline
\end{tabular}

DOI: $10.24263 / 2225-2924-2017-23-6-27$

\section{РЕСУРСО- ТА ЕНЕРГОЗБЕРІГАЮЧА ТЕХНОЛОГІЯ РЕКТИФІКОВАНОГО ЕТИЛОВОГО СПИРТУ}

\author{
А.І. Українець, Ю.В. Булій, П.Л. Шиян, А.М. Куц \\ Національний університет харчових технологій
}

У статті запропоновано технологію ректифікованого етилового спирту, щьо дає змогу підвищити ефективність видалення головних, частини проміжних i кінцевих домішок спирту в брагоректифікаційних установках з мінімальними витратами води на гідроселекиію. Представлено апаратурно-технологічну схему установки, відповідно до якої для проведення гідроселекиї в розгінній колоні здійснюють реииркуляиію кубової рідини колони екстрактивної ректифікації, в епюрачійній колоні - кубової рідини розгінної колони, а в колоні екстрактивної ректифікації - кубової рідини спиртової колони. Проведено дослідження ефективності запропонованої технології у виробничих умовах. Установлено, що ї̈ використання дає змогу скоротити питомі витрати пом'якшеної води та енерговитрати на ї̈ нагрівання до 80\% порівняно з типовими схемами брагоректифікаційних установок.

Ключові слова: ректифікаиія, кубова рідина, етиловий спирт, гідроселекиія, рециркулячія, домішки. 
Постановка проблеми. Для отримання високоякісних спиртів категорії «Люкс», «Супер-Люкс», «Пшенична сльоза» необхідне більш глибоке вилучення та концентрування органічних домішок спирту, які негативно впливають як на аналітичні, так і на органолептичні показники товарного спирту. Для цього типові брагоректифікаційні установки (БРУ) дооснащують додатковими колонами - кінцевого очищення, розгінною та колоною екстрактивної ректифікації. Особливістю роботи таких установок є необхідність проведення гідроселекції для вилучення головних і проміжних органічних домішок спирту. Гідроселекція базується на властивостях основної маси домішок збільшувати леткість при зменшенні концентрації спирту в розчині. Для здійснення гідроселекції на одну з верхніх тарілок колони подають гарячу пом'якшену воду або конденсат пари у такій кількості, при якій коефіцієнт ректифікації домішок (К) перевищує одиницю.

Аналіз даних фазової рівноваги суміші етиловий спирт-вода-домішка вказує на те, що у слабоконцентрованих водно-спиртових розчинах з концентрацією етанолу в межах $20 . .30 \%$ об. всі органічні домішки, крім метанолу і фурфуролу, мають явно виражений головний характер [1].

Ступінь вилучення $(\alpha)$ і кратність концентрування $(\beta)$ летких органічних домішок залежить від співвідношення рідинного і парового потоків $(L / G)$ та концентрації етанолу по тарілках колони. При сталих витратах потоків живлення та гріючої пари величина $L / G$ і концентрація спирту по висоті колони залежать від кількості води, що надходить на гідроселекцію.

Для виділення етилового спирту із головної фракції (ГФ) в розгінній колоні витрата гарячої пом'якшеної води на гідроселекцію становить $11,7 \ldots 26,5$ кг/кг абсолютного алкоголю (а. а.) залежно від виду сировини, питома витрата пари $200 \%$ за масою ГФ. 3 метою більш повного вилучення домішок проводять подвійну гідроселекцію, що передбачає подачу розрахункової кількості води у верхні частини концентраційних зон розгінної та епюраційної колон. При цьому концентрація етилового спирту в кубовій рідині розгінної колони знижується до $6 \ldots 8 \%$ об., а в епюраті - до $20 \ldots 25 \%$ об. За таких умов відбувається більш повне вилучення та концентрування головних і частини проміжних летких домішок, видалення яких дає змогу підвищити якість спирту та полегшити роботу спиртової колони. При цьому у ГФ, що відбирають із конденсатора епюраційної колони, більш ніж у три рази збільшується концентрація складних естерів; концентрація кислот лишається практично без змін; вміст альдегідів дещо знижується при збільшенні подачі води більше 0,72 кг/кг а. а. Витрати гарячої пом'якшеної води на зрошення епюраційної колони становлять $0,55 \ldots 0,90$ кг/кг а. а., введеного в колону. Оптимальні витрати гріючої пари знаходяться в межах 1,8...2,0 кг а. а. бражного дистиляту.

Застосування гідроселекції особливо доцільно при вилученні верхніх проміжних домішок (сивушного спирту) в розгінній колоні при концентрації кубової водно-спиртової рідини 4...4,5\% об. та нижніх проміжних домішок (вищих спиртів сивушного масла) в колоні екстрактивної ректифікації при концентрації етанолу в кубовій рідині $1,5 \ldots .3,0 \%$ об. [2].

Для проведення гідроселекції рекомендується використовувати пом'якшену воду або конденсат пари температурою $90 \ldots 92^{\circ} \mathrm{C}$. Лютерну воду вико- 
ристовують у меншій мірі через значний вміст у ній органічних кислот, які сприяють новоутворенню органічних домішок.

Недоліком відомих способів отримання ректифікованого етилового спирту в типових БРУ, оснащених додатковими колонами, є значні витрати гарячої пом'якшеної води або конденсату пари для проведення гідроселекції головних і частини проміжних домішок, а також підвищені енерговитрати на іiі нагрівання до температури, що відповідає температурі в зонах іiі подачі у відповідні колони [3; 4].

Метою дослідження $\epsilon$ розробка ресурсо- та енергозберігаючої технології ректифікованого етилового спирту за рахунок зменшення питомих витрат технологічної води для проведення гідроселекції домішок у розгінній, епюраційній колонах і колоні екстрактивної ректифікації та скорочення енерговитрат на її нагрівання шляхом рециркуляції кубової рідини спиртової, розгінної колон і колони екстрактивної ректифікації при виробництві високоякісних спиртів.

Викладення основних результатів дослідження. Для вирішення поставленої завдання авторами запропоновано здійснювати рециркуляцію кубової рідини спиртової колони для проведення гідроселекції в колоні екстрактивної ректифікації, кубової рідини колони екстрактивної ректифікації для гідроселекції в розгінній колонні, а кубової рідини розгінної колони для гідроселекції в епюраційній колоні [5].

Дослідження ефективності запропонованого способу проводились у виробничих умовах ДП «Чуднівський спиртовий завод».

Апаратурно-технологічна схема ресурсо- та енергозберігаючої брагоректифікаційної установки з використанням запропонованого способу гідроселекції летких органічних домішок спирту представлена на рис. 1.

Брагоректифікаційна установка включає бражну, епюраційну, спиртову, розгінну колони, колону екстрактивної ректифікації та колону кінцевої очистки, з'єднаних трубопроводами, а також відповідне теплообмінне обладнання. Для обігріву колон в їх нижні частини подають гріючу пару (П). При закритому обігріві відводять конденсат пари (К). Бражку (Б) послідовно подають через другу 8 та першу 7 секції бражного підігрівача, де нагрівають водно-спиртовою парою бражної колони 1 до температури, близької до температури кипіння, і далі направляють на верхню тарілку бражної колони, в якій відбувається вилучення спирту та супутніх органічних домішок з бражки. Бражний дистилят із бражних підігрівачів 7, 8 та водяної секції підігрівача 9 подають на тарілку живлення епюраційної колони 2, а конденсат пари 3 конденсатора 10 направляють на тарілку живлення розгінної колони 6. 3 кубової частини бражної колони 1 відводять барду (Бд).

В епюраційній колоні 2 здійснюють концентрування та вилучення головних i частини проміжних домішок спирту. Для цього у верхню зону концентраційної частини колони 2 подають кубову рідину розгінної колони 6. Концентровані домішки у вигляді головної фракції спирту етилового (ГФ) відводять із конденсатора 13 епюраційної колони 2.

Сивушний спирт (СС) відбирають із парової фази 18...23-ї тарілок спиртової колони 3, направляють у міжтрубний простір конденсатора 14 i після їх 
конденсації виводять з установки разом з ГФ. Сивушну фракцію (СФ) відбирають із парової фази 5, 7, 9, 11-ї тарілок колони 3. У верхній пастеризаційній частині спиртової колони 3 здійснюють концентрування головних домішок, які не в повній мірі вилучились в епюраційній колоні 2. Ці домішки у вигляді непастеризованого спирту (НС) відводять через конденсатор 16 разом з ГФ із конденсатора 13, фракціями із конденсаторів 10 і 14 на тарілку живлення розгінної колони 6 . Із рідинної фази верхніх тарілок концентраційної частини спиртової колони 3 відбирають ректифікований спирт (РС) і направляють на тарілку живлення колони кінцевої очистки 5, верхня частина якої з'єднана 3 дефлегматором 22 і конденсатором 21. У колоні 5 відбувається очищення спирту від головних і кінцевих домішок (ГКД), які відбирають із конденсатора 21 і далі направляють на верхню тарілку розгінної колони 6.

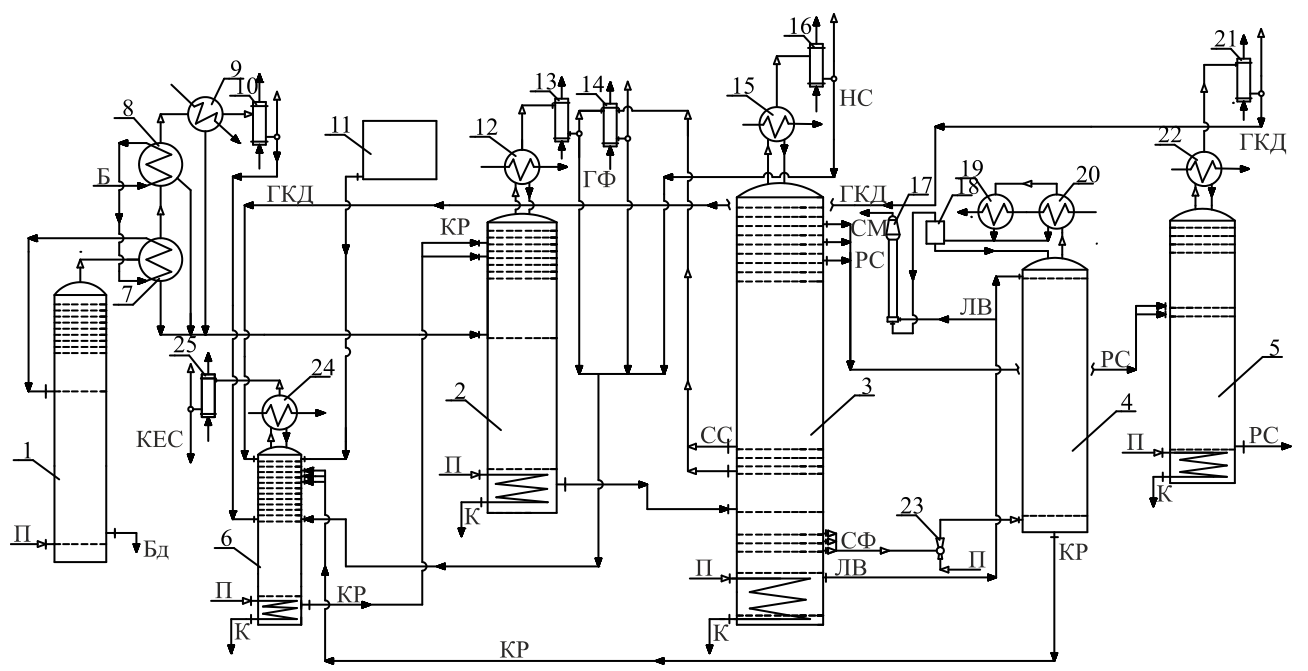

Рис. 1. Ресурсо- та енергозберігаюча брагоректифікаційна установка для отримання ректифікованого спирту високої якості

Колони: 1 - бражна; 2 - епюраційна; 3 - спиртова; 4 - екстрактивної ректифікації; 5 - кінцевої очистки; 6 - розгінна; 7, 8 - бражний підігрівач; 9 - водяна секція бражного підігрівача; 10, 13, 16, 19, 21, 25 - конденсатори; 12, 15, 20, 22, 24 - дефлегматори; 14 - конденсатор сивушного спирту; 11 - напірний збірник гарячої пом'якшеної води;

17 - екстрактор сивушного масла; 18 - декантатор; 23 - паровий ежектор.

Умовні позначення: Б - бражка; Бд - барда; ГКД - головні та кінцеві домішки;

ГФ — головна фракція спирту етилового; ЛВ — лютерна вода; СМ — сивушне масло;

СФ - сивушна фракція; РС - ректифікований спирт; НС - непастеризований спирт;

СС - сивушний спирт; КЕС - концентрат естеро-сивушний; К - конденсат; КР — кубова рідина; П — пара

3 нижньої частини колони кінцевої очистки 5 відбирають товарний ректифікований спирт. Пари (СФ) змішують 3 гріючою водяною парою в ежекторі 23 і подають в кубову частину колони екстрактивної ректифікації 4. На іiі верхню тарілку подають гарячу лютерну воду (ЛВ) 3 кубової частини спиртової колони 3. У колоні 4 відбувається вилучення та концентрування спиртів сивушного масла (CM). Конденсат парів СM із дефлегматора 20 та 
конденсатора 19 направляють в декантатор 18, де відбувається розшаровування суміші: рідину із нижньої частини декантатора 18 повертають у вигляді флегми на верхню тарілку колони 4, а СМ направляють в екстрактор 17. В нижню його частину подають лютерну воду для промивання масла. Концентроване СМ у вигляді товарного продукту відбирають з верхньої частини екстрактора 17.

Використання ЛВ спиртової колони для проведення гідроселекції у колоні екстрактивної ректифікації не впливає на якість ректифікованого спирту, оскільки звільнена від вищих спиртів сивушного масла кубова рідина колони екстрактивної ректифікації з низьким вмістом етилового спирту $(1,5 \ldots 3,0 \%$ об.) подається у концентраційну зону розгінної колони, в якій відбувається вилучення проміжних домішок, включаючи компоненти сивушного масла, та їх концентрування.

Кубову рідину (КР) колони 4 направляють на 3...5-у тарілки, рахуючи зверху, розгінної колони 6 для гідроселекції проміжних домішок, включаючи компоненти сивушного масла, та їх концентрування. На верхню тарілку колони 6 із збірника 11 подають гарячу пом'якшену воду для зниження концентрації етилового спирту в кубовій частині до розрахункової. В процесі розділення спиртовмісних фракцій в колоні 6 флегму із дефлегматора 24 повертають на верхню тарілку колони, а концентрат естеро-сивушний (КЕС) відводять із установки із конденсатора 25.

Для здійснення гідроселекції в епюраційній колоні 2 у верхню зону іiі концентраційної частини подають очищену від головних та частини проміжних домішок кубову рідину (КР) розгінної колони 6.

Облік конденсату пари для гідроселекції домішок в розгінній колоні, кубової рідини розгінної колони і лютерної води спиртової колони здійснюють за допомогою відповідних витратомірів.

Питомі витрати гарячої пом'якшеної води або конденсату пари для проведення гідроселекції домішок та питомі енерговитрати на нагрівання води (в перерахунку на 1 кг а.а., введеного в колону) відповідно до типового і запропонованого способів (табл. 1 і 2).

Таблиця 1. Питомі та загальні витрати технологічної води для проведення гідроселекції домішок

\begin{tabular}{|c|c|c|c|c|c|}
\hline \multirow{2}{*}{ Спосіб } & \multicolumn{3}{|c|}{$\begin{array}{c}\text { Питомі витрати технологічної води } \\
\text { в колонах, дм }{ }^{3} / \text { кг а. а. }\end{array}$} & $\begin{array}{c}\text { Загальні витрати } \\
\text { технологічної } \\
\text { води }\end{array}$ \\
\cline { 2 - 6 } & розгінна & епюраційна & екстрактивної ректифікації & дм³ $^{3}$ кг а. а. & $\%$ \\
\hline Типовий & 4,7 & 0,7 & 18,1 & 23,5 & 100 \\
\hline Запропонований & 4,7 & - & - & 4,7 & 20 \\
\hline
\end{tabular}

Таблиия 2. Питомі та загальні енерговитрати на нагрівання технологічної води для гідроселекції домішок

\begin{tabular}{|c|c|c|c|c|c|}
\hline \multirow{2}{*}{ Спосіб } & \multicolumn{2}{|c|}{$\begin{array}{l}\text { Питомі енерговитрати на нагрівання води для } \\
\text { проведення гідроселекції в колонах, кДж/кг а.а. }\end{array}$} & \multicolumn{2}{c|}{$\begin{array}{c}\text { Загальні } \\
\text { енерговитрати }\end{array}$} \\
\cline { 2 - 6 } & розгінна & епюраційна & екстрактивної ректифікації & кДж/кг а. а. & $\%$ \\
\hline Типовий & 590,8 & 88,0 & 2275,2 & 2951,0 & 100 \\
\hline Запропонований & 590,8 & - & - & 590,8 & 20 \\
\hline
\end{tabular}


Згідно із запропонованим способом для гідроселекції домішок в епюраційній колоні використовують кубову рідину розгінної колони, а для проведення гідроселекції в колоні екстрактивної ректифікації - кубову рідину спиртової колони, тому витрати гарячої пом'якшеної води або конденсату пари в епюраційній колоні і колоні екстрактивної ректифікації відсутні.

Запропонований спосіб дає змогу скоротити питомі витрати технологічної води та енерговитрати на ії нагрівання до $80 \%$ за рахунок рециркуляції кубової рідини спиртової, розгінної колон та колони екстрактивної ректифікації, що підтверджують дані, наведені в табл. 1 і 2.

\section{Висновки}

Результати експериментальних досліджень довели переваги запропонованого способу:

1. Використання кубової рідини спиртової колони для проведення гідроселекції в колоні екстрактивної ректифікації дає змогу скоротити витрати технологічної води на $82 \%$ порівняно з відомим способом і підвищити ефективність вилучення летких проміжних домішок.

2. Подача спиртовмісних фракцій, збагачених органічними домішками, 3 конденсаторів епюраційної та спиртової колон на тарілку живлення розгінної колони, кубової рідини колони екстрактивної ректифікації вище тарілки живлення (3...5-у тарілки, рахуючи зверху), а гарячої пом'якшеної води для гідроселекції домішок на верхню ії тарілку знижує концентрацію етилового спирту на верхніх тарілках концентраційної частини розгінної колони, завдяки чому скорочуються витрати води на гідроселекцію до $30 \%$.

3. Подача кубової рідини колони екстрактивної ректифікації на $3 . . .5$-у тарілки, рахуючи зверху, розгінної колони дає змогу утворити зону для ефективного концентрування проміжних домішок, включаючи компоненти сивушного масла.

4. Енерговитрати на нагрівання технологічної води до температури, що відповідає температурі в зонах іiі подачі у відповідні колони, скорочуються на $80 \%$ за рахунок рециркуляції кубової рідини спиртової, розгінної колони та колони екстрактивної ректифікації.

\section{Література}

1. Технологія спирту. В.О. Маринченко, В.А. Домарецький, П.Л. Шиян, В.М. Швець, П.С. Циганков, І.Д. Жолнер / Під ред. проф. В.О.Маринченко. - Вінниця : «Поділля2000», 2003. - 496 c.

2. Інноваційні технології спиртової промисловості. Теорія і практика: Монографія / П.Л. Шиян, В.В. Сосницький, С.Т. Олійнічук. - Київ : Видавничий дім «Асканія», 2009. - 424 с.

3. Патент RU на изобретение № 2243812, МПК B01 D3/14 «Способ получения ректификованного спирта» / Перегыгин В.М., Паршина Т.А., Никитина С.Ю. - Опубл. 10.01.2005.

4. Никитина С.Ю. Самотехника и методики расчетов брагоректификационных установок: монография / С.Ю. Никитина, Воронежский ГАСУ. — Воронеж, 2013. — 208 с.

5. Патент України на корисну модель № 119277, МПК B01D 3/14. Спосіб отримання ректифікованого спирту / Булій Ю.В., Шиян П.Л., Дмитрук А.П., Дмитрук П.А. Заявлено 23.01.17; Опубл. 25.09.17, Бюл. № 18. 